Хірургічна стоматологія

УДК 616.314-77-089.843-071

DOI 10.11603/2311-9624.2019.3.10572

CO. В. Добровольська

Українська медична стоматологічна академія, м. Полтава

oxana.dobr88@gmail.com

\title{
Сучасний погляд на ускладнення в дентальній імплантації
}

ІНФОРМАЦІЯ

Надійшла до редакціï/Received: 02.09.2019 p.

Ключові слова: дентальна імплантація; мукозит; периімплантит; кісткова пластика; остеоінтеграція; імплантат.
АНОТАЦІЯ

Резюме. Розвиток стоматології на сучасному етапі відкриває нові можливості в лікуванні адентії шляхом внутрішньокісткової імплантації штучних опор для зубних протезів, завдяки чому значно оптимізувалися умови для підвищення якості комплексної реабілітації стоматологічних пацієнтів. Розробка нових прийомів хірургічних втручань і протезування, створення нових систем імплантатів сприятимуть збільшенню термінів служби зубних протезів на імплантатах, поліпшенню якості життя пацієнтів.

Мета дослідження - проаналізувати літературні джерела 3 вивченням можливих ускладнень та їх причин на різних етапах реабілітації пацієнтів дентальними імплантатами.

Матеріали і методи. Проведено огляд та аналіз науково-медичної літератури за 2013-2019 pр. за базами Даних Scopus, Web of Science, Med Line, The Cochrane Library, EMBASE, Global Health, CyberLeninka, РІнЦ. Зосереджено увагу на основних причинах ускладнень дентальної імплантації.

Результати досліджень та їх обговорення. Метод дентальної імплантації знаходить все більш широке застосування в практичній стоматології при заміщенні різних дефектів зубних рядів. Дентальні імплантати різко підвищили якість ортопедичної реабілітації пацієнтів завдяки можливості застосування незнімних конструкцій зубних протезів при заміщенні дефектів зубних рядів як при частковій, так і при повній адентії. Варто відмітити, що поряд 3 позитивними результатами імплантації спостерігаються й ускладнення. До виникнення ускладнень призводять помилки, допущені на будь-якому з етапів: при плануванні, безпосередньо при проведенні операцій кісткової пластики і дентальної імплантації, в ранньому і віддаленому післяопераційних періодах, причому пов’язані як з об'єктивними, так і суб'єктивними причинами. Успіх комплексної реабілітації пацієнтів методом дентальної імплантації в умовах дефіциту кісткової тканини щелеп визначається безліччю факторів, що відіграють важливу роль на різних етапах проведення лікування. Найважливішим етапом, що забезпечує подальший успіх передбачуваного комплексного лікування пацієнтів, є ретельне обстеження, постановка діагнозу, визначення і дотримання показань і протипоказань до дентальної імплантації в умовах, далеких від оптимальних. Недостатнє врахування особливостей соматичного і стоматологічного анамнезу, скарг, мотивації і очікувань пацієнта від майбутнього лікування, даних огляду, клінічного обстеження, оцінки функціонального стану зубощелепної системи пацієнта, рівня гігієни порожнини рота, можуть призвести до невиправданості очікувань пацієнта, місцевих і загальних ускладнень. Серед об’єктивних причин, що опосередковано призводять до неточностей у діагностиці, виділяють недосконалість і недостатню інформативність променевих методів, невірне масштабування при визначенні розмірів передбачуваної ділянки для імплантації.

Висновки. Проблема пошуку оптимальних технологій імплантації, а також методів профілактики і лікування ускладнень є акту- 
альною та включає не лише розробку нових прийомів хірургічних втручань, використання додаткових заходів під час протезування, а й створення нових систем імплантатів, що повністю відповідають вимогам профілактики запальних захворювань в периімплантатній зоні. Безсумнівно, що нові досягнення в цьому напрямку будуть сприяти скороченню кількості ускладнень після імплантації у стоматологічних пацієнтів, поліпшенню якості їх життя.

Вступ. Бурхливий розвиток стоматології на сучасному рівні свого становлення відкриває нові можливості в лікуванні адентії шляхом внутрішньокісткової імплантації штучних опор для зубних протезів, завдяки чому оптимізувалися підходи до підвищення якості комплексної реабілітації стоматологічних пацієнтів. Проте актуальною проблемою стоматології залишається питання зниження кількості ускладнень після імплантації.

Найімовірніші фактори ризику можна поділити на загальні - тютюнокуріння, системну патологію, стан після променевої терапії і т. д. і місцеві - незадовільну гігієну порожнини рота, захворювання пародонта, ятрогенні стани, дизайн і якість обробки трансгінгівальної частини імплантата. Розуміння особливостей перебігу запально-деструктивних процесів навколо дентального імплантата після його установки скеровує вчених і виробників імплантатів до удосконалення консервативних і хірургічних методів лікування цих захворювань, які вже використовували, а також потребує більшої уваги до профілактики даної патології, і відповідно факторів ризику її розвитку. Розробка нових прийомів хірургічних втручань і протезування, створення нових систем імплантатів сприятимуть збільшенню термінів служби зубних протезів на імплантатах та поліпшенню якості життя пацієнтів [1].

Метою дослідження було проаналізувати літературні джерела з детальним вивченням можливих ускладнень та їх причин на різних етапах реабілітації пацієнтів дентальним імплантатами.

Матеріали і методи. Проведено огляд та аналіз науково-медичної літератури за 20132019 pр. за базами Даних Scopus, Web of Science, Med Line, The Cochrane Library, EMBASE, Global Health, CyberLeninka, РІНЦ. Зосереджено увагу на основних причинах ускладнень дентальної імплантації.

Результати досліджень та їх обговорення. Метод дентальної імплантації знаходить все більш широке застосування в практичній стоматології при заміщенні різних дефектів зубних рядів. Дентальні імплантати різко підвищили якість ортопедичної реабілітації пацієнтів завдяки можливості застосування незнімних конструкцій зубних протезів при заміщенні дефектів зубних рядів як при частковій, так і при повній адентії. Варто відмітити, що поряд із позитивними результатами імплантації спостерігаються й ускладнення. До виникнення ускладнень призводять помилки, допущені на будь-якому з етапів: при плануванні, безпосередньо при проведенні операцій кісткової пластики і дентальної імплантації, в ранньому і віддаленому післяопераційних періодах, причому пов’язані як з об'єктивними, так і суб'єктивними причинами. Успіх комплексної реабілітації пацієнтів методом дентальної імплантації в умовах дефіциту кісткової тканини щелеп визначається безліччю факторів, що відіграють важливу роль на різних етапах проведення лікування. Розглянемо докладніше причини, що призводять до розвитку вищеперерахованих ускладнень [2, 3].

Найважливішим етапом, що забезпечує подальший успіх передбачуваного комплексного лікування пацієнтів, $є$ ретельне обстеження, постановка діагнозу, визначення і дотримання показань й протипоказань до дентальної імплантації в умовах, далеких від оптимальних. Недостатнє врахування особливостей соматичного і стоматологічного анамнезу, скарг, мотивації й очікувань пацієнта від майбутнього лікування, даних огляду, клінічного обстеження, оцінки функціонального стану зубощелепної системи пацієнта, рівня гігієни порожнини рота, можуть призвести до невиправданості очікувань пацієнта, місцевих і загальних ускладнень. Нехтування використанням променевої діагностики в якості додаткових інструментально-лабораторних методів дослідження або помилки в їх інтерпретації неприпустимі для коректної оцінки якісних і кількісних характеристик кісткової тканини щелеп у зоні передбачуваної імп- 
лантації. Неточне визначення індивідуальних анатомічних особливостей, необ'єктивна оцінка патологічних процесів у кістці та питання необхідності проведення кістковореконструктивних операцій, точної їх топографії та об’єму, часто є причиною невиправданого розширення показань до дентальної імплантації.

Серед об'єктивних причин, що опосередковано призводять до неточностей діагностики, виділяють недосконалість і недостатню інформативність променевих методів, невірне масштабування при визначенні розмірів передбачуваної ділянки для імплантації $[4,5]$.

При плануванні кістково-реконструктивних операцій у пацієнтів із дефіцитом кісткової тканини недостатній аналіз, невірна інтерпретація діагностичних даних ведуть до виникнення ряду помилок, що ініціюють різного роду ускладнення. Припущення помилок можливо на будь-якому з етапів планування, якими є: вибір адекватної методики кістково-реконструктивної операції; виду кістково-замінного матеріалу, форми його випуску, способу та якості його індивідуального моделювання, розрахунок необхідної його кількості, способу введення, накладення, визначення його точного орієнтування; вибір методики дентальної імплантації; вибір дентального імплантата, його вид, форма, розмір, матеріал виготовлення, кількість, точне планування майбутньої позиції імплантата в кістковій тканині щелепи з урахуванням її рентгенологічних характеристик, співвідношення 3 антагоністами, поруч із розміщеними зубами, протетичної площині; вибір початку функціонального навантаження на дентальний імплантат і виду ортопедичної конструкції [6].

Найбільша точність в плануванні об’єму біоматеріалу, його розташування, розстановки дентальних імплантатів досягається на підставі високотехнологічних методів променевої діагностики із застосуванням спеціалізованого програмного забезпечення. На даному етапі розвитку технологій стало можливим створення анатомічних і тривимірних моделей щелеп, що дозволяє правильно спланувати операцію кісткової пластики та імплантації, математично розрахувати й обгрунтувати місця їх встановлення [7, 8].

Основна кількість помилок і ускладнень, що виникають на етапі кістково-реконструктивної операції, пов'язані з недоліками діагностики і планування на попередніх етапах.
Це невдалий вибір кістково-замінного матеріалу, його об’єму, складність надання йому необхідної форми в операційному полі, адаптації до форми реципієнтного ложа, складнощі у позиціонуванні й фіксації, дефіцит м'яких тканин при ушиванні рани, а також рівень складності обраної техніки виконання, ïї травматичність.

Помилки діагностики та планування, недосконалість або недотримання обраної хірургічної техніки дентальної імплантації супроводжуються такими ускладненнями, як перфорація дна верхньощелепного синусу або стінки нижньощелепного каналу, кровотеча, перегрів кісткової тканини при формуванні ложа імплантата, перелом інструмента, перфорація компактного шару нижньої щелепи, ухилення від оптимальної осі передбачуваного дентального імплантата, неточне його позиціонування, відсутність первинної стабільності його. Важливими обставинами є також складність виконання, тривалість і травматизм обраної методики дентальної імплантаціï.

Період від проведення дентальної імплантації до протезування характеризується виникненням таких ускладнень, як післяопераційні кровотечі, гематоми, розвиток синуситів і невритів, ранніх мукозитів та периімплантитів, відсутністю стабільності імплантата, відторгненням його, міграцією імплантата під слизову оболонку та ін. Більшість з них є наслідком помилок, допущених на попередніх етапах [9].

Частота периімплантитів підвищує ймовірність дезінтеграції і навіть відторгнення імплантата. У свою чергу, запальний процес, що розвивається в слизовій оболонці й нерідко зумовлює виражену кісткову деструкцію в периімплантатній зоні, призводить до неспроможності й повної втрати імплантата майже в 52-67 \% випадків. Під час вивчення даної проблеми виявлено наявність кореляційної взаємозв’язку між ступенем тяжкості патологічних процесів, що розвиваються в периімплантатних тканинах, і ступенем резорбції кісткової тканини.

Дентальна імплантація як метод лікування часткової та повної адентії за останні півтора десятиліття завоювала міцні позиції у сучасній ортопедичній стоматології. Аналіз ринку стоматологічних послуг свідчить про те, що щорічно в світі встановлюється більш 2 млн імплантатів [10-12]. 
Експериментальні та морфологічні дослідження мають велике значення в дослідженні остеоінтеграції при дентальній імплантації, особливо при спробах оптимізувати даний процес. Сучасне уявлення про нього представлено у вигляді концепції морфологічного обгрунтування використання дентальних імплантатів, що базується на підставі параметрів адаптації кісткової тканини до введеного в неї чужорідного тіла трактується як остеоінтеграція - прямий структурний і функціональний зв'язок між впорядкованою живою кісткою і поверхнею імплантата. При цьому загоєння кісткової рани після проведення оперативного втручання перебігає в суворій відповідності з загальними закономірностями ремоделювання кісткової тканини.

Важливим напрямком є дослідження питань, пов'язаних із регенерацією кісткової тканини і лікування післяопераційних ускладнень. Ділянка оперативного втручання - рановий кістковий шар піддається значним змінам в ранні терміни після операції. Ступінь ушкодження даної ділянки багато в чому визначає інтенсивність розвитку і вираження післяопераційних запальних реакцій, а отже, тривалість процесів регенерації кісткової тканини і повноцінності функціонування дентального імплантата в подальшому $[13,14]$.

Більшість наукових робіт, присвячена цій темі, вивчають різного роду деталі й особливості хірургічного та протетичного етапів даного стоматологічного втручання. Запропоновано і відпрацьовано методики впровадження імплантатів у кісткову тканину, форма коренеподібних імплантатів провідних виробників розрахована за допомогою комп’ютерного моделювання, на вибір пропонуються різні види різьблення для різних типів кісткової тканини.

Незважаючи на те, що імплантація в останні роки вирізняється високим рівнем успіху в ранньому післяопераційному періоді, актуальною проблемою стоматології залишається можливість віддалених ускладнень, пов'язаних перш за все з розвитком запалення тканин, що оточують остеоінтегрірованний імплантат, поява яких негативно впливає на збереження самих імплантів. Так, за даними аналізу публікацій останніх років, у результаті виниклих патологічних змін в тканинах, що оточують внутрішньокістковий імплантат, випадки невдалих результатів лікування складали від 4 до 12 \% і більше [15-18].
Відомо, що надійне функціонування дентальних імплантатів залежить від індивідуального стану організму, гігієни порожнини рота, пов'язане з відсутністю запально-деструктивних явищ в периімплантатній зоні після установки імплантатів. Не виключено, що саме конкретні порушення біоценозу тканин ясен і системи локального імунного захисту створюють передумови для формування патогенетичної основи, завдяки якій відбувається розвиток затяжних запальнодеструктивних процесів у периімплантатній ділянці, тобто дентального периімплантиту. Виходячи 3 вищенаведених позицій, представляє інтерес вивчення змін показників мікробіоценозу периімплантаційної зони, рівнів місцевого імунітету та інтерлейкінів у динаміці спостережень. Належить з'ясувати чи можуть перераховані показники слугувати в якості об'єктивних критеріїв результатів дентальної внутрішньокісткової імплантації [19].

Результати аналізу сучасних літературних джерел вказують, що на сучасному етапі питань дослідження диференційного підходу до лікування запальних явищ у кістковій тканині щелеп не приділяється належної уваги. Поодинокі публікації, що зачіпають окремі аспекти даної проблеми, носять поверхневий описовий характер і не оперують об'єктивними даними, отриманими на підставі принципів доказової медицини. Таким чином, дослідження етіопатогенетичних факторів виникнення і розвитку периімплантиту, своєчасна діагностика і розробка оптимальних та ефективних лікувально-профілактичних засобів мають важливе практичне значення та $є$ актуальним напрямком розвитку дентальної імплантації [20, 21].

Висновки. Зважаючи на зростання незадоволення пацієнтів результатами комплексної реабілітації з використанням дентальних імплантатів 3 причини виникнення різного роду ускладнень, стає очевидним, що існує необхідність точного об'єктивного аналізу вихідної клінічної ситуації і планування комплексного лікування, використання цифрових діагностичних даних для реалізації цифрового планування, цифрового проектування, навігації в умовах оперативного втручання, формулювання чітких цифрових обгрунтувань для визначення показань до проведення реконструктивних операцій і дентальної імплантації, оскільки це дозволяє індивідуалізу- 
вати підхід до кожного конкретного пацієнта, а отже, прогнозувати і знизити кількість невдач у лікуванні. Таким чином, проблема пошуку оптимальних технологій імплантації, а також методів профілактики і лікування ускладнень, є актуальною і включає не лише розробку нових прийомів хірургічних втручань, використання додаткових заходів під час протезування, а й створення нових систем імплантатів, що повністю відповідають вимогам профілактики запальних захворювань у периімплантатній зоні. Безсумнівно, що нові досягнення в цьому напрямку будуть сприяти скороченню кількості ускладнень після імплантації у стоматологічних пацієнтів, поліпшенню якості їх життя.

\section{(С). В. Добровольская}

Украинская медицинская стоматологическая академия, г. Полтава

\section{Современный взгляд на осложнения в дентальной имплантации}

Резюме. Развитие стоматологии на современном этапе открывает новые возможности в лечении адентии путем внутрикостной имплантации искусственных опор для зубных протезов, благодаря чему появились новые возможности в повышении качества комплексной реабилитации стоматологических пациентов. Разработка новых приемов хирургических вмешательств и протезирования, создание новых систем имплантатов способствуют увеличению сроков службы зубных протезов на имплантатах, улучшению качества жизни пациентов.

Цель исследования - проанализировать литературные источники с изучением возможных осложнений и их причин на различных этапах реабилитации пациентов дентальными имплантатами. Материалы и методы. Проведен обзор и анализ научно-медицинской литературы за 2013-2019 гг. по базам данных Scopus, Web of Science, Med Line, The Cochrane Library, EMBASE, Global Health, Cyber Leninka, РИНЦ. Сосредоточено внимание на основных причинах осложнений дентальной имплантации.

Результаты исследований и их обсуждение. Метод дентальной имплантации находит все более широкое применение в практической стоматологии при замещении различных дефектов зубных рядов. Дентальные имплантаты резко повысили качество ортопедической реабилитации пациентов благодаря возможности применения несъемных конструкций зубных протезов при замещении дефектов зубных рядов как при частичной, так и при полной адентии. Стоит отметить, что наряду с положительными результатами имплантации наблюдаются и осложнения. К возникновению осложнений приводят ошибки, допущенные на любом из этапов: при плантировании, непосредственно при проведении операций костной пластики и дентальной имплантации, в раннем и отдаленном послеоперационных периодах, причем связанные как с объективными, так и субъективными причинами. Успех комплексной реабилитации пациентов методом дентальной имплантации в условиях дефицита костной ткани челюстей определяется множеством факторов, играющих важную роль на различных этапах проведения лечения. Важнейшим этапом, обеспечивающим дальнейший успех предполагаемого комплексного лечения пациентов, является тщательное обследование, постановка диагноза, определения и соблюдения показаний и противопоказаний к дентальной имплантации в условиях, далеких от оптимальных. Недостаточный учет особенностей соматического и стоматологического анамнеза, жалоб, мотивации и ожиданий пациента от предстоящего лечения, данных осмотра, клинического обследования, оценки функционального состояния зубочелюстной системы пациента, уровня гигиены полости рта, могут привести к неоправданности ожиданий пациента, местным и общим осложнениям. Среди объективных причин, косвенно приводящим к неточностям диагностики, выделяют несовершенство и недостаточную информативность лучевых методов, неверное масштабирование при определении размеров предполагаемого участка для имплантации.

выводы. Проблема поиска оптимальных технологий имплантации, а также методов профилактики и лечения осложнений является актуальной проблемой и включает в себя не только разработку новых приемов хирургических вмешательств, использование дополнительных мероприятий во время протезирования, но и создание новых систем имплантатов, которые полностью соответствуют требованиям профилактики воспалительных заболеваний в периимплантатний зоне. Несомненно, что новые достижения в этом направлении будут способствовать сокращению количества осложнений после имплантации в стоматологических пациентов, улучшению качества их жизни.

ключевые слова: дентальная имплантация; мукозит; периимплантит; костная пластика; остеоинтеграция; имплантат. 


\section{(C) O. V. Dobrovolska}

Ukrainian Medical Dental Academy, Poltava

\section{A modern view on complications in dental implantation}

Summary. The development of dentistry at the present stage opens up new possibilities in the treatment of adentia by means of the intraosseous implantation of artificial supports for dentures, which opened up new opportunities for improving the quality of comprehensive rehabilitation of dental patients. The development of new methods of surgical interventions and prosthetics, the creation of new implant systems help to increase the life of dentures on implants, improve the quality of life of patients.

The aim of the study - literary sources analysis with the study of possible complications and their causes at various stages of patient rehabilitation with dental implants.

Materials and Methods. The review and analysis of scientific-medical literature for the years 2013-2019 was conducted, according to the databases Scopus, Web of Science, Med Line, The Cochrane Library, EMBASE, Global Health, CyberLeninka, RINC. Attention is focused on the main causes of complications of dental implantation.

Results and Discussion. The method of dental implantation is increasingly used in practical dentistry in the replacement of various defects in the dentition. Dental implants dramatically increased the quality of orthopedic rehabilitation of patients due to the possibility of using fixed dentures in the replacement of dentition defects in both partial and complete adentia. It is worth noting that along with the positive results of implantation, complications are also observed. Complications are caused by errors made at any stage: during planning, directly during bone grafting and dental implantation, in the early and long-term postoperative periods, both related to objective and subjective reasons. The success of comprehensive rehabilitation of patients by dental implantation in conditions of jaw bone deficiency is determined by many factors that play an important role at various stages of treatment. The most important stage ensures the further success of the proposed comprehensive treatment of patients, a thorough examination, diagnosis, determination and compliance with indications and contraindications for dental implantation in conditions that are far from optimal. Inadequate consideration of the characteristics of the somatic and dental anamnesis, complaints, motivation and expectations of the patient from the upcoming treatment, examination data, clinical examination, assessment of the functional state of the patient's dentofacial system, level of oral hygiene, can lead to unjustified expectations of the patient, local and general complications. Among the objective reasons that directly lead to inaccuracies in diagnosis are the imperfection and lack of informational content of radiation methods, incorrect scaling when determining the size of the proposed site for implantation.

Conclusions. The problem of finding optimal implantation technologies, as well as methods for the prevention and treatment of complications, is relevant and includes not only the development of new surgical procedures, the use of additional measures during prosthetics, but also the creation of new implant systems that fully comply with the requirements for the prevention of inflammatory diseases in the peri-implant zone. Undoubtedly, new advances in this area will help to reduce the number of complications after implantation in dental patients, and improve their quality of life.

Key words: dental implantation; mucositis; peri-implantitis; bone grafting; osseointegration; implant.

\section{СПИСОК ЛІТЕРАТУРИ}

1. Пономаренко В. О. Віддалені результати незнімного протезування хворих похилого віку з повною вторинною адентією нижньої щелепи 3 опорою на імплантати / В. О. Пономаренко, М. В. Хребор, Ю. І. Силенко // Український стоматологічний альманах. - 2017. - № 3. - С. 29-31.

2. Мащенко И. С. Факторы риска и прогнозирования развития воспалительных осложнений и локального вторичного остеопороза в костных структурах челюстей при дентальной внутрикостной имплантации у здоровых пациентов / И. С. Мащенко, А. А. Гударьян, С. В. Ширинкин // Медичні перспективи. - 2013. - № 1. - С. 19-27.

3. Характеристика осложнений при использовании метода дентальной имплантации в условиях атро- фии альвеолярной кости челюстей / Н. В. Попов, Е. А. Ищенко, Е. В. Новикова [и др.] // Вестник медицинского института «Реавиз»: реабилитация, врач и здоровье. - 2019. - № 1 (37). - С. 97-102.

4. Использование компьютерных технологий для анализа ошибок и осложнений дентальной имплантации / И. Ю. Петров, А. И. Петров, Ю. А. Ипполитов, Л. В. Бут // Вестник новых медицинских технологий. Электронное издание. - 2014. - № 1. - DOI: $10.12737 / 4798$

5. Гараев 3. И. Снижение риска развития осложнений дентальной имплантации / 3. И. Гараев, Р. А. Джавадов, Х. Б. Насирова // Современная стоматология. - 2014. - № 2 (59). - С. 74-76.

6. Количественная оценка рентгенологических па- 
раметров альвеолярной кости челюстей в результате реконструктивных операций / Г. П. Котельников, Д. А. Трунин, Н. В. Колсанов [и др.] // Медицинский вестник Северного Кавказа. - 2019. - № 1. - С. 97-100. 7. Оценка состояния альвеолярной кости вокруг дентальных имплантатов, установленных после выполнения костнопластических операций, по данным рентгенологического анализа / А. А. Кулаков, А. Г. Надточий, Т. В. Брайловская [и др.] // Медицинский альманах. - 2015. - № 3 (38). - С. 178-179. 8. Клинико-рентгенологическое обоснование имплантации искусственных опор зубных протезов на верхней челюсти / А. А. Матчин, В. Н. Барков, Е. Г. Мац [и др.] // Вятский медицинский вестник. 2019. - № 2 (62) . - С. 8-12.

9. Проблема воспаления в периимплантатных тканях и факторы, влияющие на его течение : обзор литературы / Д. В. Михальченко, А. Т. Яковлев, Е. Ю. Бадрак, А. В. Михальченко // Волгоградский научно-медицинский журнал. - 2015. - № 4 (48). С. 15-18.

10. Клинико-рентгенологическая диагностика периимплантатного мукозита и дентального периимплантита хронического течения / Е. С. Головина, Е. А. Кузнецова, В. П. Тлустенко [и др.] // Известия Самарского научного центра РАН. - 2014. - № 6-1. C. 330-335.

11. Влияние технологии протезирования зубов на динамику ранних предикторов воспалительно-деструктивного процесса в периимплантатной зоне / В. П. Тлустенко, И. М. Байриков, Д. А. Трунин [и др.] // Вестник РГМУ. - 2019. - № 2. - С. 44-47.

12. Recommendations on the clinical application of air polishing for the management of peri-implant mucositis and peri-implantitis / F. Schwarz, K. Becker, K. D. Bastendorf [et al.] // Quintessence Int. - 2016. No. 47 (4). - P. 293-296.

13. Хирургические методики формирования десневого края на втором этапе имплантации / О.В.Добровольская,А.В.Добровольский,И.В.Павлиш,

\section{REFERENCES}

1. Ponomarenko, V.O., Khrebor, M.V., \& Sylenko, Yu.I. (2017). Viddaleni rezultaty neznimnoho protezuvannia khvorykh pokhyloho viku $\mathrm{z}$ povnoiu vtorynnoiu adentiieiu nyzhnoi shchelepy z oporoiu na implantaty [Long-term results of permanent prosthetics of elderly patients with complete secondary adenitis of the mandible with support for implants]. Ukrainskyi stomatolohichnyi almanakh - Ukrainian Dental Almanac, 3, 29-31 [in Ukrainian].

2. Mashchenko, I.S., Gudaryan, A.A., \& Shirinkin, S.V. (2013). Faktory riska i prognozirovaniya razvitiya vospalitelnykh oslozhneniy i lokalnogo vtorichnogo osteoporoza v kostnykh strukturakh chelyustey pri dentalnoy vnutrikostnoy implantatsii u zdorovykh patsiyentov [Risk factors and prediction of the development of inflammatory complications and local secondary osteoporosis in the bone structures of the jaws with dental intraosseous implantation in healthy patients]. Medychni perspektyvy - Medical Prospects, 1, 19-27 [in Russian].
Л. А. Луговая // Український стоматологічний альманах. - 2016. - № 4. - С. 87-90.

14. Калбаев А. А. Возможности применения коротких имплантатов при значительной атрофии альвеолярного отростка челюстей / А. А. Калбаев, А. Ж. Нурбаев, Р. Р. Тынчеров // Проблемы науки. 2017. - № 5 (87). - C. 84-88.

15. TLR4 mediates alveolar bone resorption in experimental peri-implantitis through regulation of $\mathrm{CD}_{4}+$ cell infiltration, RANKL/OPG ratio, and inflammatory cytokine production / S. Deng, Y. Hu, J. Zhou [et al.] // J. Periodontol. - 2019. - doi: 10.1002/ JPER.18-0748.

16. Basis of bone metabolism around dental implants during osseointegration and peri-implant bone loss / A. Insua, A. Monje, H. L. Wang, R. J. Miron // J. Biomed Mater Res A. - 2017. - No. 105 (7). - P. 2075-2089.

17. The pathology of bone tissue during peri-implantitis / B. Schminke, F. Vom Orde, R. Gruber [et al.] // J. Dent. Res. - 2015. - No. 94 (2). - P. 354-361.

18. Role of toll-like receptor 2 in inflammation and alveolar bone loss in experimental peri-implantitis versus periodontitis. / X. Yu, Y. Hu, M. Freire [et al.] // J. Periodontal. Res. - 2018. - No. 53 (1). - P. 98-106.

19. Clinical and radiographic peri-implant parameters and whole salivary interleukin- $1 \beta$ and interleukin-6 levels among type-2 diabetic and nondiabetic patients with and without peri-implantitis / M. Al-Askar, S. Ajlan, N. Alomar, N. M. Al-Daghri // Med. Princ. Pract. - 2018. No. 27 (2). - P. 133-138.

20. Definition, etiology, prevention and treatment of periimplantitis-a review / R. Smeets, A. Henningsen, O. Jung [et al.] // Head Face Med. - 2014. - No. 10. doi:10.1186/1746-160X-10-34

21.ШевелаТ. Л. Экспериментально-морфологическое обоснование дифференцированного подхода к лечению периимплантита / Т. Л. Шевела, И. О. Походенько-Чудакова, С. Л. Кабак // Вісник проблем біології і медицини. - 2018. - № 3 (145). - С. 336-339.

3. Popov, N.V., Ishchenko, Ye.A., Novikova, Ye.V., Ippolitov, A.A., \& Borisova M.A. (2019). Kharakteristika oslozhneniy pri ispolzovanii metoda dentalnoy implantatsii v usloviyakh atrofii alveolyarnoy kosti chelyustey [Characterization of complications when using the method of dental implantation in conditions of atrophy of the alveolar bone of the jaw]. Vestnik meditsinskogo instituta "Reaviz": reabilitatsiya, vrach $i$ zdorovye - Bulletin of the Medical Institute "Reaviz": Rehabilitation, Doctor and Health, 1 (37), 97-102 [in Russian].

4. Petrov, I.Yu,. Petrov, A.I., Ippolitov, Yu.A., \& But, L.V. (2014). Ispolzovaniye kompyuternykh tekhnologiy dlya analiza oshibok i oslozhneniy dentalnoy implantatsii [Use of computer technologies for the analysis of errors and complications of dental implantation]. Vestnik novykh meditsinskikh tekhnologiy. Elektronnoye izdaniye - Bulletin of New Medical Technologies. Electronic edition, 1. doi:10.12737/4798 [in Russian].

5. Garayev, Z.I., Dzhavadov, R.A., \& Nasirova, Kh.B. 
(2014). Snizheniye riska razvitiya oslozhneniy dentalnoy implantatsii [Reducing the risk of complications of dental implantation]. Sovremennaya stomatologiya Modern Dentistry, 2 (59), 74-76 [in Russian].

6. Kotelnikov, G.P., Trunin, D.A., Kolsanov, N.V., Popov, L.V., Limanova, L.V., \& Novikova Ye.V. (2019). Kolichestvennaya otsenka rentgenologicheskikh parametrov alveolyarnoy kosti chelyustey $\mathrm{v}$ rezultate rekonstruktivnykh operatsiy [Quantitative assessment of the radiological parameters of the jaw alveolar bone as a result of reconstructive operations]. Meditsinskiy vestnik Severnogo Kavkaza - Medical Bulletin of the North Caucasus, 1, 97-100 [in Russian].

7. Kulakov, A.A., Nadtochiy, A.G., Braylovskaya, T.V., Bedretdinov, R.M., \& Magomedov, R.N. (2015). Otsenka sostoyaniya alveolyarnoy kosti vokrug dentalnykh implantatov, ustanovlennykh posle vypolneniya kostnoplasticheskikh operatsiy, po dannym rentgenologicheskogo analiza [Assessment of the state of the alveolar bone around dental implants installed after osteoplastic surgery, according to x-ray analysis]. Meditsinskiy almanakh - Medical Almanac, 3 (38), 178179 [in Russian].

8. Matchin, A.A., Barkov, V.N., Mats, Ye.G., Bakanov, N.A., \& Ovcharenko, T.Yu. (2019). Klinikorentgenologicheskoye obosnovaniye implantatsii iskusstvennykh opor zubnykh protezov na verkhney chelyusti [Clinical and radiological substantiation of implantation of artificial supports of dentures in the upper jaw]. Vyatskiy meditsinskiy vestnik - Vyatsky Medical Bulletin, 2 (62), 8-12 [in Russian].

9. Mikhalchenko, D.V., Yakovlev, A.T., Badrak, Ye.Yu., \& Mikhalchenko, A.V. (2015). Problema vospaleniya v periimplantatnykh tkanyakh i faktory, vliyayushchiye na yego techeniye (obzor literatury) [The problem of inflammation in peri-implant tissues and factors influencing its course (literature review)]. Volgogradskiy nauchno-meditsinskiy zhurnal - Volgograd Scientific Medical Journal, 4 (48), 15-18 [in Russian].

10. Golovina, Ye.S., Kuznetsova, Ye.A., Tlustenko, V.P., Sadykov, M.I., \& Tlustenko, V.S. (2014). Klinikorentgenologicheskaya diagnostika periimplantatnogo mukozita i dentalnogo periimplantita khronicheskogo techeniya [Clinical and radiological diagnosis of periimplant mucositis and chronic dental peri-implantitis]. Izvestiya Samarskogo nauchnogo tsentra RAN - Bulletin of Samara Scientific Center of the Russian Academy of Sciences, 6-1, 330-335 [in Russian].

11. Tlustenko, V.P., Bayrikov, I.M., Trunin, D.A., Gusyakova, O.A., \& Komlev, S.S. (2019). Vliyaniye tekhnologii protezirovaniya zubov na dinamiku rannikh prediktorov vospalitelno-destruktivnogo protsessa v periimplantatnoy zone [Impact of dental prosthetics technology on the dynamics of early predictors of the inflammatory and destructive process in the periimplant zone]. Vestnik RGMU - Herald of the RSMU, 2, 44-47 [in Russian].
12. Schwarz, F., Becker, K., Bastendorf, K.D., Cardaropoli, D., Chatfield, C., \& Dunn I. (2016). Recommendations on the clinical application of air polishing for the management of peri-implant mucositis and periimplantitis. Quintessence Int., 47 (4), 293-296.

13. Dobrovolskaya, O.V., Dobrovolskiy, A.V., Pavlish, I.V., \& Lugovaya, L.A. (2016). Khirurgicheskiye metodiki formirovaniya desnevogo kraya na vtorom etape implantatsii [Surgical techniques of gingival margin formation at the second stage of implantation]. Ukrainskyi stomatolohichnyi almanakh - Ukrainian Dental Almanac, 4, 87-90 [in Russian].

14. Kalbayev, A.A., Nurbayev, A.Zh., \& Tyncherov, R.R. (2017). Vozmozhnosti primeneniya korotkikh implantatov pri znachitelnoy atrofii alveolyarnogo otrostka chelyustey [Possibilities of using short implants with significant atrophy of the alveolar ridge of the jaw]. Problemy Nauki - Problems of Science, 5 (87), 84-88 [in Russian].

15. Deng, S., Hu, Y., Zhou, J., Wang, Y., Wang, Y., \& Li, S. (2019). TLR4 mediates alveolar bone resorption in experimental peri-implantitis through regulation of $\mathrm{CD} 45+$ cell infiltration, RANKL/OPG ratio, and inflammatory cytokine production. J. Periodontol. doi:10.1002/JPER.18-0748.

16. Insua, A., Monje, A., Wang, H.L., \& Miron, R.J. (2017). Basis of bone metabolism around dental implants during osseointegration and peri-implant bone loss. $J$. Biomed. Mater. Res. A.,105 (7), 2075-2089.

17. Schminke, B., Vom Orde, F., Gruber, R., Schliephake, H., Bürgers, R., \& Miosge, N. (2015). The pathology of bone tissue during peri-implantitis. J. Dent. Res., 94 (2), 354-361.

18. Yu, X., Hu, Y., Freire, M., Yu, P., Kawai, T., \& Han, X. (2018). Role of toll-like receptor 2 in inflammation and alveolar bone loss in experimental peri-implantitis versus periodontitis. J. Periodontal. Res., 53 (1), 98-106.

19. Al-Askar, M., Ajlan, S., Alomar, N., \& Al-Daghri, N.M. (2018). Clinical and radiographic peri-implant parameters and whole salivary interleukin-1 $\beta$ and interleukin-6 levels among type-2 diabetic and nondiabetic patients with and without peri-implantitis. Med. Princ. Pract., 27 (2), 133-138.

20. Smeets, R., Henningsen, A., Jung, O., Heiland, M., Hammächer, C., \& Stein, J.M. (2014). Definition, etiology, prevention and treatment of periimplantitis - a review. Head Face Med., 10. doi:10.1186/1746-160X-10-34.

21. Shevela, T.L., Pokhodenko-Chudakova, I.O., \& Kabak, S.L. (2018). Eksperimentalno-morfologicheskoye obosnovaniye differentsirovannogo podkhoda $\mathrm{k}$ lecheniyu periimplantita [Experimental and morphological substantiation of a differentiated approach to the treatment of peri-implantitis]. Visnyk problem biolohii i medytsyny - Bulletin of Problems of Biology and Medicine, 3 (145), 336-339 [in Russian]. 